\section{Human Hubris, Anthropogenic Climate Change, and an Environmental Ethic of Humility}

Organization \& Environment

(C) The Author(s) 2021

Article reuse guidelines: sagepub.com/journals-permissions DOI: $10.1177 / 10860266211039000$ journals.sagepub.com/home/oae

(SSAGE

\author{
Eugene Sadler-Smith' and Vita Akstinaite ${ }^{2}$ (D)
}

\begin{abstract}
This article is about how hubris, individually and collectively, has contributed to the climate emergency and how an environmental ethic of humility could play an ameliorating role in the crisis. It focuses on the relationship between virtue ethics and the natural environment, and it argues that a collective "human hubris" ("The Problem") has contributed significantly to anthropogenic climate change and that a "humility-based approach" toward the environment that entails an appreciation of humanity's proper place in the natural order ("A Solution"). In it, we combine theories from the social and environmental sciences to propose an environmental ethic of humility as an "antidote" to human hubris by which leaders and other stakeholders could steer institutions, organisations, and behaviour towards environmental virtuousness. We also suggest the environmental ethic of humility as a benchmark against which stakeholders could be held to account for the environmental impacts of their actions. The article discusses the implications of hubris and humility in the areas governance, consumer behaviour, reputation, learning and education, accountability, and critical reflexivity.
\end{abstract}

\title{
Keywords
}

climate change, environmental ethics, hubris, humility

\section{Introduction}

Researchers acknowledge that the "ensemble of problems" associated with anthropogenic climate change cannot be analysed or addressed without contributions from the humanities and social sciences (Agrawal \& Orlove, 2012, p. 329). In this article, we focus on the relationship between virtue ethics and the natural environment and argue that humanity's hubris, individually and collectively, has contributed significantly to the climate emergency and that an environmental ethic of humility could play a role in ameliorating the situation. In the behavioural sciences, hubris is defined as a grandiose sense of self, characterised by over-confidence, arrogance, contempt towards the advice and criticism of others (Akstinaite et al., 2020; Sadler-Smith \& Tourish, 2021). Hubris causes individuals to create conditions that invite unintended negative consequences due to their overestimating the likelihood of positive outcomes and underestimating the likelihood of

\footnotetext{
'University of Surrey, Guildford, England, UK

${ }^{2}$ ISM University of Management and Economics, Vilnius, Lithuania
}

\section{Corresponding Author:}

Eugene Sadler-Smith, Surrey Business School, University of Surrey, Guildford GU2 7XH, UK.

Email: e.sadler-smith@surrey.ac.uk 
negative outcomes from their decisions and actions. These behaviours and attitudes are evinced in humanity's attitude collectively towards the natural environment. Humility towards the natural environment informed by climate change awareness: first, entails an appreciation of nature's grandeur as well as its vulnerability and fragility, and of humanity's culpability in the climate emergency and its proper place in the natural order; second, is an important environmental virtue which could inform debate and catalyse humility as an "adaptation practice" (Brugger \& Crimmins, 2013; D. R. Nelson et al., 2020) in the face of the current climate emergency.

Trust and confidence in the power of scientific discovery have resulted in extraordinary human progress in terms both of technological achievements and societal improvements (Bordoni, 2019). Science and technology have fueled economic growth, raised standards of living, improved human health and well-being, and extended longevity (Harari, 2014). However, the technologies that are the products of scientific invention and innovation are not risk-free or unproblematic (R. Owen et al., 2012; Pidgeon et al., 2008).

The most problematic technologies and, as it turns out, riskiest as far the Earth's climate is concerned are those based on fossil fuel consumption. It is indisputable that the reckless use of coal, oil and gas, and concomitant release of carbon dioxide into the Earth's atmosphere since the onset of the Industrial Revolution is the primary cause of anthropogenic global warming. ${ }^{1}$ Human beings, both individually and collectively, have been overconfident, overambitious, and overzealous in their use of fossil fuel-based technologies. They have simultaneously displayed ignorance, arrogance, and contempt towards the effects of fossil fuel consumption on the natural environment. However, the climate change message has now been articulated clearly and communicated widely such that ignorance is no longer a reason for environmentally unethical behaviours, and arrogance and contempt should be reined in. The latter allied to overconfidence, overambition, and recklessness are the hallmarks of hubris (Akstinaite et al., 2020; Sadler-Smith, 2019), and hubris - that is of individuals themselves and the organisations and institutions of which they are a part-is becoming acknowledged in climate change messaging as a significant source of the problem ${ }^{2}$ (D. R. Nelson et al., 2020).

In this article, hubris and humility are positioned as part of a wider system of environmental virtue ethics (EVE) whereby: (1) stakeholders, such as leaders, managers, employees, and consumers, could navigate away from environmentally hubristic behaviors and towards environmentally virtuous behaviors in acknowledgement of the urgent need to reduce greenhouse gas (GHG) emissions; (2) stakeholders could evaluate their own and others' actions and thereby be more accountable for any environmentally unethical behaviors which contribute to unsustainably high GHG emissions. This could be achieved, for example, by organisations being required to establish clear reporting requirements which identify activities that transgress environmental virtues. This article offers an outline framework for how this could be achieved. In so doing, we explore the relationships between human hubris, anthropogenic climate change, and environmental virtuousness by bringing together disparate literatures from the social and environmental sciences. We offer proposals for how institutions and organisations, as well as policy makers and other stakeholders (including consumers), might conduct themselves in less environmentally hubristic and more environmentally virtuous ways.

\section{The Problem}

Industrialised nations and business organisations have been the main drivers of economic growth and prosperity over the past three centuries, however, they have also been collectively hubristic in their overconfident and reckless use of fossil fuel-based technologies. This manifestation of modernity has placed Homo sapiens as the de facto controller of the Earth's climate (Hulme, 2014). But with power comes responsibility, and the unethical use of power invites negative consequences (Midgley, 2003). 
Over two millennia ago, the Greeks warned, metaphorically speaking, of the dangers of "flying too close to the sun" in their Icarus myth. Icarus became recklessly overconfident in his newfound and God-like power of flight, he ignored the wise warnings of his father Dædalus, and paid the ultimate price for his hubris. One interpretation of this myth is that Icarus perished because of his naïve belief in the power, and hubristic application, of technology. The myth is a cautionary tale that can inspire "social science engagement" (Agrawal \& Orlove, 2012, p. 330). A climate emergency has materialised out of humanity's Icarus-like unchecked ambition and overconfidence in the power of its technologies. This is analogous to a climatic "Frankenstein effect," and the problem has been amplified by disregarding the warnings from climate scientists that stretch back many decades. ${ }^{3}$

In terms of Homo sapiens' relationship with its environment, its collective hubris manifests as: (1) apathy and indifference: habituated behaviors that are environmentally harmful without being deliberately so; (2) arrogance: indifference to nature coupled with overvaluation of ourselves and undervaluation of others setting ourselves up as "tyrants over the rest of creation"; (3) gluttony: such as in the mindless pursuit of "more and more stuff" (Jamieson, 2007, p. 481) and fueling environmentally harmful intensive agriculture by the over-consumption of certain food types; (4) greed: privileging short-termism, growth as an end in itself and maximising shareholder value and profit above other motives, fostering widespread overconsumption, and ultimately leading to wider harms; (5) ignorance: some moral agents, at least until recently, were ill-equipped to take environmentally responsible actions because of lack of knowledge whilst others may have been guilty of willful myopia and blindness. The latter has allowed humanity's bold ambition and inventive genius (Bordoni, 2019) to go hand-in-hand with selective blindness, thus enabling "capitalism to freeride on nature and the environment" (Wright \& Nyberg, 2015, p. 28).

Hubris can be an individual-level phenomenon (D. Owen \& Davidson, 2009; Picone et al., 2014) or a collective construct at the level of organisations, institutions, and even whole societies (Bordoni, 2019; Ford, 2006; Ladd, 2012; Mason, 2004). Ehrlich and Ehrlich (2004, p. 9) referred to this as "social hubris." Collective human hubris has emerged out of the complex interactions between people, technology, goals, culture, processes, and context, which have led to behaviors that are overambitious and overconfident to the point of recklessness. Humanity's hubris has manifested in unsustainable increases in human population, GDP, energy consumption, and carbon emissions (see the "Kaya identity"; Kaya, 1989).

These interactions and the triumphs of technology create conditions for the emergence of unintended negative consequences (Picone et al., 2014; Sadler-Smith et al., 2017; Taleb et al., 2009), see "sociotechnical systems theory" (Eason, 1982; Leavitt, 1965; Mumford, 2006; Pasmore, 1988). For example, in health care systems, unanticipated and undesirable consequences often undermine patient safety practices and occasionally harm patients (Harrison et al., 2007). Outcomes may be the intended consequences of linear, predictable cause-and-effect relationships or they can be the unintended consequences of nonlinear, hard-to-predict, complex relationships (Helbing, 2009). Likewise, in the predictive modelling of environmental hazards, human hubris can lead us to embrace deterministic representations that mask uncertainties and fail to account for path-dependent trajectories that create risks across time (Manuel-Navarrete et al., 2019; D. R. Nelson et al., 2020). The complexity of our sociotechnical systems demands an approach that is characterised by humility rather than hubris and an acknowledgement in science and public policies of the radical uncertainties of "what we don't know" about the consequences of our actions (Verbruggen, 2013).

But this does not amount to any claim that hubris is inexorably followed by nemesis. The philosopher Mary Midgley argued that the hubris-nemesis pairing cannot be framed in terms of a simple linear cause-and-effect relationship; however, it can be framed in terms of "getting what we asked for" on the basis that bad consequences are not just a matter of chance. Acts that are morally wrong in themselves can be reasonably expected to have adverse effects, and as such, 
their outcomes are a sign of what was wrong with the act in the first place (Midgley, 2003). Framed in this way, the relationship between collective hubris and anthropogenic climate change is a moral question fundamentally, and entailing issues of virtue and environmental ethics. In Midgley's terms, the bad outcome (global warming) signals that the act (reckless use of fossil fuels) was morally wrong in the first place. The hubristic act is morally wrong in that it is an act of excess.

Collective hubris (Sullivan \& Hollway, 2014)—also referred to as "organisational hubris"has been cited as a contributory factor in various financial, geopolitical, and environmental calamities across different contexts including the following: the collapse and U.S. treasury bail-out of the hedge fund firm Long-Term Capital Management in 1998 and which threatened the stability of the U.S. financial system (Lowenstein, 2000); the 2008 global financial crisis (Sadler-Smith, 2019); the NASA Challenger and Columbia space shuttle disasters in 1986 and 2003, respectively (Mason, 2004); the 2003 invasion of Iraq (Beinart, 2010); the BP Deepwater Horizon oil spill in the Gulf of Mexico in 2010 (Ladd, 2012); and global warming (McIntosh, 2012). In each of these examples, the organisations were hubristic, that is, guilty of collective grandiosity and overconfidence, and arrogance and contempt towards the advice and criticism of others embedded within their cultures. For example, in the Challenger disaster, NASA managers were contemptuous towards the expert advice of the Morton Thiokol engineers that typified the hubristic culture of the organisation, in the case of Deepwater BP overreached itself technically, and in the Iraq invasion the Bush cabinet members colluded and complied as one with the President's hubristic behaviours. None of these examples, it is argued, could have happened had hubris been confined to an individual leader. In many of these cases, the collective arrogance was fuelled by a hubristic tone from the top, which has led Andrew Bailey, the current governor of the Bank of England, to call for a formal assessment of hubris risk alongside other forms of risk that are routinely accommodated in risk assessments such as capital risk (Bailey, 2018) and Mark Carney, a former Governor of the BoE, to call for humility in leadership (Carney, 2021). This suggested a two-pronged approach of formal risk assessment allied to a virtue-based approach entailing humility as a leader virtue that is selected for and encouraged. More generally, Bordoni (2019) categorises this as a presumptuous tendency of humanity to go beyond its limits in pursuit of "progress" but with concomitant effects of indifference and greed. For example, greed has been identified by Haynes et al. (2015) as being associated with hubris in entrepreneurial contexts and as having combined effects on inappropriate entrepreneurial behaviours with related effects on ESG issues.

At both the individual and the collective levels, hubris does not entail behaviors that are deliberately destructive. For example, BP did not seek a blow out, subsequent loss of life and catastrophic oil spill at Deepwater Horizon in the Gulf of Mexico in 2010. As summarised by Folkersen et al. (2019, p. 3), economic losses from the Deepwater Horizon oil spill "were created by human behaviour in the deep sea, not by the ecosystems of the deep sea." It happened because, according to Ladd (2012), BP overreached themselves and, in so doing, created the conditions out of which unintended negative consequences were able to emerge. In other words, collective hubris helps create the conditions for the emergence of unintended negative consequences ("nasty surprises") (MacKay \& Chia, 2013; Rescher, 1996; Sadler-Smith, 2019). Leaders' behaviours can lead to hubris by result not by intention, and even where decision-makers are not indifferent or ignorant (and indifferent or ignorant persons only become Presidents or CEOs on a minority occasions, thankfully), there is no guarantee that their actions will not be hubristic, hence the need for better governance, risk assessment and moral character. ${ }^{4}$ This raises a more general point in that in responding to the challenge of climate change, it is not a question of either ethics or compliance, the solution lies in both compliance and control (e.g., through governance and risk assessment, as well as changes to the rules of the market) and moral character (e.g., by selecting and appointing leaders who display the relevant virtues of humility and practical wisdom). The solution is both compliance/control and character not either compliance/control or character. 
A core problem of collectively hubristic organisations and institutions is that the biggest risk management mistake lies within the fabric of the organisation or institution itself and its relationships with other elements of the sociotechnical system. For example, in the Deepwater Horizon oil spill and the 2008 financial crisis, individual organisations and entire industries overestimated their ability to control events and whilst simultaneously underestimating what could go wrong. They hubristically overlooked path-dependent trajectories and the potential for negative outcomes, which makes organisations and institutions particularly vulnerable to low probability/ high impact events ("black swans"; Taleb et al., 2009). Hubris creates the conditions for normal accidents (Perrow, 1984) to arise especially given the perils of "black swans" and "unknown unknowns," hence the need for prudence and precaution. Moreover, an economic system that ignores externalities (such as the effects of pollution in oil and gas exploration and production) is likely to foster a continuance of collectively hubristic behaviours. In the absence of fair pricing that includes negative externalities, actors are likely to persist in behaviours that are counter to the interests of the whole Earth system. A further advantage of fair pricing is that it highlights to consumers the consequences of their actions and prompts reflective inquiry into the morality of their actions. For example, increasing air travel costs have both an economic effect (air travellers pay more) and an educative effect (air travellers understanding more about and accepting the potential consequences of their actions).

In the case of anthropogenic climate change, several factors compounded the hazards associated with collective human hubris: (1) the widespread use of fossil fuel-based technologies since the Industrial Revolution gave the appearance of stability but actually stored-up the possibility of a catastrophic events for the future (Kennedy, 2012; Rand, 2010); (2) system-wide effects of increased $\mathrm{CO}_{2}$ levels in the atmosphere were foreseeable from the 1970 s based on scientific principles established in the nineteenth century, but were overlooked or ignored (Rich, 2019); (3) the occurrence of individual high-impact extreme weather events associated with anthropogenic climate change (such as heat waves, excessively cold winters, cyclones, etc.) are much less easy to predict, and have the added complication that they lead to weather and climate being conflated and fueling climate change denial (Li et al., 2013; Otto et al., 2018); (4) local consequences of global $\mathrm{CO}_{2}$ increases can be easily discounted by individuals because they are perceived to be distal both temporally ("it isn't happening for me right now") and spatially ("it won't happen for me right here"; Ackerman et al., 2009). However, the reality is that there are both proximal and distal pathways from climate-induced environmental change to human health and wellbeing related to issues such as food security, migration and mobility in different geographic locations over different timescales (Cinner \& Barnes, 2019; Loebach \& Korinek, 2019; G. P. Morris et al., 2017). Future generations across the globe may end-up paying the highest price.

The complex interdependencies between people, technology, culture, goals, and processes in complex adaptive systems (Rammel et al., 2007) can create the conditions in which actors fail to manage risks appropriately. The problem is compounded by overconfidence in the power of technology, a hubristic "tone from the top" of organisations and institutions and the risk of "epistemic hubris," which can render individuals impervious to criticism and learning (Ladd, 2012; Mason, 2004; Picone et al., 2014; Sadler-Smith, 2019) thus causing them to overlook, underestimate, or willfully ignore risks (Rich, 2019). In Aristotelian virtue ethics, this is an attitude that is ultimately "against reason" and contrary to practical wisdom (phronesis). Arguably the real failure was a "willful blindness," the "refusal to pay attention" and becoming separated from and oblivious to our conscious rational selves-a self which we "ignore at our peril" (Heffernan, 2012). There was, at minimum, willful blindness on the part of a number of business organizations and political leaders on the matter of climate change from the 1970s (Rich, 2019). On the other hand, epistemic humility appears to be "in very short supply in some areas of environmental economics and policy," as in the view that massive geoengineering for carbon capture and storage is a viable "first-line defense against climate change" thus presenting further and on-going evidence of 
epistemic hubris-it simply adds "more of the same" (J. A. Nelson, 2013, p. 152). The problem would not be solved through the humility-based approach that we are suggesting here (since $\mathrm{CO}_{2}$ levels are high and rising and $\mathrm{CO}_{2}$ will persist as a result of past collective hubris) but nonetheless, a humility-based approach could help mitigate the situation by slowing and ultimately stopping the increases by accelerating the trajectory towards net-zero (whilst acknowledging that it cannot reverse past actions, the "sins [or vices] of the fathers" so to speak).

In many highly organised systems, especially complex sociotechnical systems, subsystems are so tightly intertwined that if something goes seriously wrong in one of them, the effects ramify and amplify, and the whole system becomes susceptible to instability and potential disaster (Perrow, 1984; Roberts \& Bea, 2001). Several factors are at work in complex systems: the complex nature of the systems themselves, actors' limited abilities to understand and control complex sociotechnical systems, and an illusion of control that gives rise to collective hubris (Burns \& Machado, 2010). In anthropogenic climate change, within a minutely short geological time span, human actors introduced powerful technologies that possessed endogenous risks that exceeded actors' capacity to fully understand and regulate them (Beck, 1997). Significant dangers arise when the complexity and novelty of innovations exceed actors' capacity to fully understand and anticipate their potential impacts and thus give rise to a "Frankenstein effect" (Burns \& Machado, 2010, p. 97); in the case of climate change Dr. Frankenstein's monster turns out to be fossil fuels. Highly rational actors acting in concert are capable of extraordinary feats of exaggerated self-confidence, self-deception, willful blindness, and commitment to illusions of control (Heffernan, 2012; Langer, 1975; Trivers, 2011).

Sociotechnical systems are, as alluded to above, rife with externalities. In the case of anthropogenic climate change, the externalities have been overlooked largely (Lindsey \& Santos, 2020), but they underscore the moral issue at the heart of the problem. Ignoring externalities will have a negative effect on future generations who will be the ultimate bearers of the costs. The moral implications are magnified in light of the fact that "we understood the reality of anthropogenic climate change and failed to do anything about it" (Oreskes, 2004, p. 1686). The eminent ecologists Paul Ehrlich and Anne Ehrlich (2004) in their book One With Nineveh: Power, Politics and Human Consumption framed this as a hubris that "induces people to believe that the environment can somehow be put on hold and repaired later if society deems it necessary and throws enough money and new technology at it" (p. 9). When future generations of humans reflect on the negative effects of previous generations' preferences, habits, and behaviors on the stability of the whole Earth system, they will be seen as an unintended but avoidable consequence not only of the failings of individual leaders but of humanity's collective hubris. When viewed as an affront to future generations, such behaviour embodies hubris in its original ancient Greek and purest formulation, that is as hybris (úv $\beta \rho 1 \zeta)$, which meant an insult, insolence or an outrage (Cairns, 2020). Homo sapiens' collective hubris with respect to the exploitation of fossil fuelbased technologies and the concomitant effects on Earth's climate is a moral issue in that it jeopardises the well-being and thriving (eudaimonia) of current and future generations, is contrary to practical wisdom (phronesis) and antithetical to virtue (McManus, 2018; Petit \& Bollaert, 2012; Trumbull, 2010). The hubris-based misuse of power has led to increasing overpopulation and runaway consumption (Ehrlich \& Ehrlich, 2004); essentially, the problem is of one of scale, which is redolent of an anthropocentric grandiosity.

\section{A Solution}

Science exists in a paradoxical relationship with anthropogenic climate change. On the one hand, the Industrial Revolution's technological developments based on Enlightenment science have led, albeit inadvertently, to global warming, on the other, science has revealed the extent of the climate emergency. Some climate scientists themselves, such as the University of Cambridge's 
Professor Mike Hulme, have argued that at this juncture, a different but complementary way of engaging with the challenge and mobilising change on the part of our institutions, our leaders, and ourselves is required. ${ }^{5}$ Even though the public debate about anthropogenic climate change is morally charged and ethically challenging, research into the role of morality and ethics in climate change is "still scarce" (Besio \& Pronzini, 2014, p. 287). An alternative is to be found in the "vital contributions" alluded to in the introduction that humanities and social sciences can and should make to debate, policy, and action (Agrawal \& Orlove, 2012, p. 329).

Climate change is a complex ethical "grand challenge" that our current sociotechnical system has struggled to fix (Jamieson, 2007). Prominent environmental scientists, such as Hulme (2014) and others, have invoked "virtue" as one way of responding to climate change. For example, in Hell and High-Water (2011) Alistair MacIntosh invokes the virtue of "hope," the anthropologist Tim Leduc in Climate, Culture and Change (2010) invokes "wisdom," and Shelia Jasanoff writing in Nature invokes "humility" (Jasanoff, 2007).

The "solution" offered in this article is not a "fix" for the problem of anthropogenic climate change, it is a proposal for thinking differently, and more critically and reflexively, about the "upstream" roots of the problem. The proposed solution is recognising the importance of humility in the face of the potentially existential crisis that human hubris has created. Humility is categorised here as a virtue (and in contrast to the vice of hubris), but it is acknowledged that other relevant virtues are recognised in the ethics and environmental ethics literatures (Lane, 2011). The climate crisis is framed as a moral problem and motivator for political and individual action. Relevant theories from virtue and environmental ethics are presented to further develop the argument for an environmental virtue of humility.

\section{Virtue Ethics}

This article is concerned with how we should act in the face of a potential climate crisis. Finding an answer to this is a moral question that requires a practical philosophical system. No single philosophical system has the answer. This article adopts virtue ethics as a pragmatic moral philosophy for organizations (Crossan et al., 2013; Sadler-Smith, 2012; Solomon, 2003) because understanding virtues can help business leaders make better decisions by providing practical guidance on "what sort of things should be done and with motivation to do them" (Audi, 2012, p. 273, italics in original) rather than appealing to abstract philosophical principles (Whetstone, 2001).

Virtues are dispositions of moral character which motivate, guide, and correct ethical behavior towards some end or purpose ("telos"; Whetstone, 2005). The exercising of virtue is an end in itself, it is part of a well-lived life as instantiated in Aristotle's concept of "Eudaimonia" (usually translated as meaning "flourishing," "doing well," "living well"; Solomon, 2003). MacIntyre (1984, p. 140) points out that virtues: (1) are dispositions not only to act in particular ways but also to "feel in particular ways"; (2) must be comprehended and exercised in relation to the community in which they arise. The application of virtue ethics to the natural environment is appropriate as it broadens the notion of community (originally the "polis" or city-state in Aristotle's ethics) to encompass the biosphere and the whole-Earth system (Cafaro \& Sandler, 2010).

Virtue ethics as a philosophical system offers substantive, instrumental, and normative benefits for dealing with the challenges of anthropogenic climate change as follows: (1) substantively: through the incorporation of virtue into public discourse stakeholders' knowledge and understanding can be modified; (2) instrumentally: the exercise of virtue can inspire and deliver change; (3) normatively; because it is "right" and "good" to be virtuous (Hulme, 2014). Moreover, practitioners and policy makers have yet to leverage fully the potential of virtue as an environmental ethical "instrument" and as a means for countering climate change and holding individuals, organisations and institutions to account for their actions. ${ }^{6}$ 


\section{Environmental Ethics}

Environmental ethicists aim to understand and determine the norms and behaviors that govern the relationship between humans and the natural environment (Sandler, 2005). In his foundational work, Environmental Ethics Rolston (1988) set out the fundamental principle of environmental ethics: humans must live in response to nature, accept responsibility for nature, and optimise human fitness on Earth by seeking "practically urgent" answers to the question "what human behavior is morally appropriate?" Environmental ethics is a theory and a practice of appropriate concern for, values in, and duties regarding the natural world and environmental ethicists situate the environment as the object of ethical discourse, not merely as its arena (Cafaro, 2005; Leopold, 1949/2003; Palmer, 2003; Rolston, 2003) ${ }^{7}$

EVE define virtues as "the proper dispositions or character traits for human beings to have regarding their interactions and relationships with the environment" (Sandler, 2005, p. 3). EVE acknowledges the importance of positive dispositions of human moral character (i.e., virtues) as a means of preserving the integrity, stability, and beauty of the environment (Sandler, 2005) alongside legislation and mandates to preserve the environment. The former (EVE) aligns with the precepts of "positive deviance" and the shift from a concern with "deficit gaps" to a focus on "abundance gaps" (Hoffman \& Haigh, 2011).

An environmentally virtuous agent is someone who is disposed to "respond to [do] the right thing, for the right reason, and in the right way, while also having the right desires and feelings about it" (Sandler, 2013, p. 1667). The ways in which an organisation routinely and habitually behaves towards the environment expresses its collective environmental ethic (Sadler-Smith, 2013). Moreover, it is those members of the organisation who hold and wield power who ultimately "can be held responsible for the [moral] character of the institutions of which they are principal agents" (O’Neill et al., 2008, p. 215).

Environmental virtuousness is in our "enlightened self-interest" (Cafaro, 2005, p. 31) based on the principles that: (1) environmental virtues are good for humanity and for the Earth and vice versa; (2) environmental vices not only harm nature, they harm individuals and the communities of which they are a part (Cafaro, 2005); (3) being environmentally benevolent reaffirms our human nature which is to "dwell in virtuous relations with the non-human environment as relational beings acting in specific moral, social, historical and ecological contexts" (Frasz, 2005, p. 133); (4) environmental virtues should promote human flourishing and justice, even if this requires short-term sacrifices for long-term gains, and invites reappraisal of commonly accepted habits, preferences, and values (Wenz, 2005).

\section{Humility-based Approach}

A fundamental task for EVE is specifying which character traits are environmental virtues and which are environmental vices (Sandler, 2013). Sandler (2013, p. 1669) makes a basic distinction between vice and virtue and offers some examples: (1) "hubris, indifference, apathy, greed, wastefulness, and laziness" are vices; (2) "humility, courage, benevolence, temperance, perseverance, integrity, and wonder" are virtues. Scholars from the social, physical, and environmental sciences have focused attention on and proposed humility as an "antidote" to hubris (D. R. Nelson et al., 2020; Sadler-Smith \& Cojuharenco, 2020) and highlighted humility as an environmentally important virtue (Hulme, 2014, see above).

The virtue of humility has a rich heritage in theology and philosophy, stretching back to Ancient Greeks, Taoists, and Buddhists (J. A. Morris et al., 2005; Owens et al., 2013). Humility entails a "forgetting of the self" allied to a deep appreciation of the worthiness of others (Chang \& Diddams, 2009), see also the concept of 'the small self' and its relationship to 'awe' (Piff et al., 2015). Some consider humility to be foundational amongst the virtues in that it affords moral agents a 
tempering influence, "saving grace" or "antidote" that guards against excesses, such as confidence or ambition thereby, helping individuals to be more grounded (Grenberg, 2005; Owens et al., 2013). In Ancient Greece, sophrosyne - encompassing humility, restraint, self-control, and temperance - was the virtue that could bring people "back from the abyss" of hubris-followed-bynemesis (De Haan \& Kasozi, 2014, p. 262). Nussbaum (1988) described the virtue of humility as: (1) requiring considering oneself as "small"; (2) constituting proper behaviour towards one's worth and is particularly relevant when interpreted as physical scale, one's relationship to the Earth (see 'small self'); (3) a disposition to choose well. ${ }^{8}$ Some scholars also consider humility to be distinctive in that it is "sort of meta-virtue" (Sousa \& van Dierendonck, 2017, p. 17) that sustains other virtues (Grenberg, 2005) and hence supportive of "choosing well."

Within the overall ethical architecture of humility versus hubris, what might a generic virtue of humility, and its converse hubris, look like in the context of the environment? Based on selected the environmental ethics literature (see Cafaro, 2005; Frasz, 2005; Jamieson, 2007; Sadler-Smith, 2013; Sandler, 2013; Schultz \& Zelezny, 1999; van Wensveen, 2005; Wardekker et al., 2009; Wenz, 2005; Wilson, 1994) the following suggestions are offered.

In terms of the relationship between hubris and humility, environmental hubris (Niemann, 2017) is associated with "domination, techno-fixes, and anthropocentrism" (Sandler, 2012, p. 9), whereas humility towards the natural environment is positively deviant and intercedes against and counters the negative deviance of hubris. Environmental humility pays close attention to ecosystems and not just our own desires' and affords us a "self-restraint which places a brake on our ambitions" (Higgs, 2012, p. 95). A person who has humility towards the natural environment would be "horrified at the prospect of changing the Earth's fundamental systems and would act in such a way as to minimise the impact of their behavior" (Jamieson, 2007, p. 480). Over-and-above the physical harms to the planet that the International Panel on Climate Change (2014) and others have identified, acting with contempt towards the natural environment is fundamentally wrong. As Midgely (2004) notes, such systematic bad acts have negative effects and destructive consequences, and accepting those consequences is an integral part of the act itself. There is enough evidence available for stakeholders to have sufficient knowledge to be fully aware of the consequences of their actions. Hence by engaging in such acts they are accepting that: (1) the negative consequences of their hubris are part of the hubristic act itself, (2) in behaving hubristically they are inviting such consequences to occur, (3) the consequences are likely to be detrimental to themselves as well as the human and natural communities of which they are a part.

Practical ways in which stakeholders can step away from this moral precipice include acknowledging our limits, reattuning our thinking so that we are not blind to our own shortcomings, recognising errors and learning from mistakes, and communicating the climate change consensus coherently (D. R. Nelson et al., 2020). We now consider the implications of an environmental virtue of humility.

\section{Implications}

The language of virtue has been largely absent from climate change debate in business, instead, the discourse has been framed in terms of economics, politics, science, and technology, nonetheless, there have been some calls for a "broader intellectual engagement" (Castree et al., 2014, p. 763). Acknowledging that virtue is a viable adaptation strategy and practice (Agrawal \& Orlove, 2012; Brugger \& Crimmins, 2013; D. R. Nelson et al., 2020) puts philosophy on an equal footing with economics, politics, science, and technology in the debate. Hence, it is not a question of either economics, politics, science, and technology or philosophy; instead, the solution to a problem as complex as anthropogenic climate change is likely to emerge from interdisciplinarity, that is both from philosophy and from other disciplines (Gardiner, 2004). 
In the face of the challenge, it would be tempting to assent to the view that anthropogenic climate change is a global macro-level problem, and therefore only global public policy solutions are likely to work. Key policy instruments that shape incentives to reduce carbon emissions include taxes, trading based on the allocations of property rights, and regulation, and the solution needs to be global and collective (Stern, 2006). But as Stern also notes, we must augment macro-level policy incentives by considering possibilities for changing actors' preferences, beliefs, and habits at the micro-level. Stakeholders in public institutions and business organisations (including executives, managers, and customers) are key actors in this debate. Moreover, a virtue-based approach is not incommensurate with or obstructive of policy interventions. With these issues in mind, we explore some of the implications for corporate governance, organisational reputation, other stakeholders, learning and education, measurement and monitoring, and recursivity and reflexivity.

\section{Implications for Corporate Governance}

Recent years have witnessed increased accountability pressures on institutions and organisations, both public and private, for improved sustainability reporting, and as the climate emergency intensifies, such pressures are likely to increase. One way organisations seek to demonstrate and be held accountable for good governance is to use their annual reports to disclose environmental information to shareholders and other stakeholders (K. Gibson \& O’Donovan, 2007). Such reports often focus on tangibles such as environmental protection measures, cleanup costs, emissions data, but rarely address the moral foundations that provide the ethical framework upon and within which such behaviours are enacted.

Virtue offers a framework by which companies' ethical behavior and "moral motives" can be scrutinised (Graafland \& Van de Ven, 2006, p. 1). For example, in their environmental reports business organisations might be expected to scrutinise their behaviors, or be scrutinised, in ways that acknowledge the environmental virtues of appreciation (Nyberg \& Wright, 2012; Stern, 2006; Wilson, 1994), attunement (van Wensveen, 2005), benevolence (Frasz, 2005; Schultz \& Zelezny, 1999), position (van Wensveen, 2005) and reciprocity (Wenz, 2005). Likewise, the vices articulated above of apathy and indifference, arrogance, gluttony, greed, and willful ignorance could be the counter attributes that characterise hubris. Humility-hubris could be an ethicsbased lens through which external stakeholders (governments, nongovernmental organizations, and pressure groups) could analyse corporate environmental behavior and hold governments, institutions, organisations, and leaders to account. For example, in business introducing and incorporating a humility-based approach as part of a company's ethical compliance reporting voluntarily would give organisations the "moral firepower" (Arjoon, 2005, p. 343) to build confidence and trust in their leaders' commitment to environmental ethics, see also Carney (2021) below. UNESCO has identified a number of international documents that could be used as a basis for internally agreed ethical principles relevant to climate change (e.g., precautionary principle, common but differentiated responsibilities, safeguarding and promoting the interests of current and future generations, polluter pays principle, etc.) but recommended a "rethinking" of how we formulate problems and draw on the principles of ethics (UNESCO, 2010, p. 24). Hubris and humility are one way in which the problem could be reformulated from an EVE perspective.

It might be feasible to develop an agreed international standard based on the environmental virtues cited above, with humility at the core as the counterforce to hubris. Organisations could use the language of a humility-based approach to develop a corporate code of ethics for the internal governance of climate change as an alternative, or complement, to following a legal compliance route (Hormio, 2017) or the applying of existing principles to the problem (UNESCO, 2010). Annual reports and other forums could provide companies with opportunities to record 
compliance in terms of a bespoke "corporate code for climate change." These issues are linked closely to organisational reputation.

\section{Implications for Organisational Reputation}

Climate change is a scientific, social, and strategic issue for governments, institutions, and organisations, for example, in business, elevating corporate reputation is one reason why companies reduce GHG emissions voluntarily (Hoffman, 2005). Poor environmental performance can significantly and negatively influence the ethical perception of a company (Lin et al., 2016). Environmental irresponsibility can be addressed through mandated legal enforcement; however, an ethical compliance approach has advantages for corporations, including mitigating potential reputational harm (Arjoon, 2005). An ethical compliance approach would emphasise environmental virtues and a humility-based approach as principles that guide corporate choices (rather than a set of strictures to be adhered to), and ethical compliance is geared towards engaging in responsible conduct rather than avoiding unlawful conduct. Moreover, it would treat ethics as infused into business practice. The ethical compliance approach to climate change could be rooted in a set of environmental moral values subsumed under the meta-virtue of humility and provide a framework by which corporate reputation might be judged. A preliminary list might include appreciation, attunement, benevolence, position, and reciprocity with humility at the core (see above). Commitment to an environmental virtue of humility has the potential to reap both economic, ethical and environmental benefits (see Lin et al., 2016). The former governor of the Bank of England, Mark Carney, in a recent treatise on values, what is wrong with the economy as it is now and how to build a better world, has argued strongly for a mix of: first, moral leadership (and in the present context this should be environmental-virtues based and capitalise on social solidarity around climate issues); and second, the development of standard metrics for companies' environmental performance (which in the terms set out here should encompass environmental virtues; Carney, 2021). The latter could be part of a broader mandating of companies to make comprehensive and transparent climate-related disclosures (see "Implications for Corporate Governance" above).

The time is right for such an approach. Whilst discussions regarding ethics, the environment and ethical compliance are long-standing, there appears to have been a sea change recently whereby stakeholders, especially "millennials" and postmillennials (so-called "Gen Z"), are highly alert to anthropogenic climate change issues (e.g., the Greta Thunberg "phenomenon"). It is doubtful whether consumers in the second decade of the 21 st century are as poorly informed about climate change as they have been depicted in previous research (Arnold \& Bustos, 2005). Climate change has received such widespread publicity in recent years that ignorance can no longer be an excuse or explanation. The culpability of business in contributing to the global warming problem clashes with the much higher ethical and environmental expectations of companies held by millennials and postmillennials (Ng et al., 2010; Weber \& Urick, 2017). This makes virtue and a humility-based approach an essential topic for "intergenerational ethics" and extending to those generations not yet born who are likely to bear the brunt of the effects of anthropogenic climate change (Gardiner, 2006).

\section{Implications for Other Stakeholders}

We are all consumers, and consumers are a vital stakeholder group whose complicity must be acknowledged when considering the relationships between organisations' ethical behaviour and environmental issues. A reciprocal relationship exists between the supply of goods and services that organisations provide and the demand by consumers for goods and services. To change the character of consumption in rich countries, the consumer can be a powerful lever of change in the 
pursuit of sustainable development (Sanne, 2002). Insights from ecological economics, which bridges several fields of inquiry, are potentially useful in understanding the role of consumers as stakeholders given that it: (1) focuses on the embeddedness of humans in their "ecological lifesupport system" and (2) recognises of scale in relation to sustainability. Whilst the focus in traditional economics has been on self-interest, ecological economics is concerned with "our identity as persons in community" (Costanza et al., 2014) and hence is commensurable with the Aristotelian notion of human flourishing (eudaimonia) in the community (polis). The notion of "community" is extended from that of the "human community" to the "whole Earth community." This article reinforces the bridge from ecological economics to Aristotelian virtue ethics (focusing on the virtue of humility) to consumer behaviour and the meanings of "happiness."

Bina and Vaz (2011, p. 170) call for a debate that challenges the meaning of "growth" (Jackson, 2009) and makes a plea for a "more holistic understanding of human beings" as economic actors who are "quintessentially relational" and who need to acknowledge responsibility to community, society, and nature as well as to the needs of the self. Max-Neef (2010) identifies a "finite, few, and classifiable" set of human needs that are observable across cultures and history, namely: needs for subsistence, protection, affection, understanding, participation, idleness, creation, identity and freedom that are satisfiable through "being" (qualities), "having" (things), "doing" (actions) and "interacting" (settings). Bina and Vaz (2011) noted that virtue addresses acting for the good of the self and for the good of the community, and the "entry point" for individuals framed as the question "what should I do in order to behave in an environmentally virtuous way?" is consistent with an ethic of humility and contrary to the vices associated with hubris (apathy arrogance, gluttony, greed, ignorance, and indifference). Consumers as economic agents can cultivate humility as a character trait that facilitates a shift in their behaviour and concomitantly in socioeconomic systems away from excessive consumption and unlimited growth and towards frugality and sustainability. Hence, consumers as stakeholders have a responsibility to choose their values and goals instead of "passively receiving them from empowered political or economic structures" (Bina \& Vaz, 2011, p. 174). There is some evidence that COVID-19 may provide an opportunity for a positive recalibration of working and consumption patterns and appreciation of nature and the environment, which could facilitate a transition towards a more sustainable economic system (Rousseau \& Deschacht, 2020). One of the broader lessons to be drawn from the pandemic is humility (Jones, 2020).

A society with greater humility at the levels of its institutions, organisations, and its individual moral agents towards the environment would need to rethink how it organised its structures in ways that were commensurate with an environmental ethic of humility. Ultimately, environmental humility is likely to entail the recognition by all stakeholders that economic activity must be reconfigured to be able to sustain a limited number of people rather than try to facilitate evergreater consumption by ever-more people. An environmental ethic of humility could help foster a transition towards Sustainable Consumption and Production. Sustainable Consumption and Production seeks to fulfil the needs of all using fewer resources, especially energy and water, producing less waste and pollution whilst contributing to poverty alleviation and an energy transition, but it requires a holistic approach and the engagement of numerous stakeholders (United Nations Environment Programme, 2015).

The pursuit of sustainable consumption as a means to sustainable development is about both individual moral character and the ethical climate within which the individual is situated, hence any analysis of the role that consumers play must also acknowledge the structural factors in society that produce and enable excessive consumption and greed (Sanne, 2002). Urban populations, in the main, hold a utilitarian view of the environment founded in an anthropocentric view of the global ecosystem, and this view rooted in human exceptionalism (Jasanoff, 2021) is perhaps the "great hubris of human history" (Stephens, 2012). Education and reflexivity are potential mechanisms for engaging stakeholders and changing mind-sets. 


\section{Implications for Learning and Education}

The cultivation of virtue is an appropriate response to the challenges of anthropogenic climate change, and learning and education has a vital role to play (Hulme, 2014). For example, in business, university business schools and corporate training departments could seek to cultivate and teach "modes of knowing" about climate change that go beyond the scientific and technical (Jasanoff, 2007). This could include foundational knowledge of the science of climate change, principles of ecological economics as a counter to those of traditional economics, and virtue ethics, for example, addressing basic questions such as "what is humility?" and "how does it relate to hubris?" but also ethical debates about the organisational, social, and political ramifications of anthropogenic global warming. Ecological economics per se also deserves a more prominent position in the curricula of schools of business, economics and management. Teaching climate change crosses the disciplinary boundaries of humanities, social science, and the physical sciences. Moreover, it should involve asking the "so what" questions about implementation and include representative cases and illustrations of what success and failure might look like (Aragon-Correa et al., 2017).

The kinds of pragmatic questions that might be considered in debating the practicalities of environmental virtuousness and a humility-based approach in real businesses as well as case studies of business might include the following: (1) how much do this business "value" the future; (2) how much influence and relevance this business allocate to different current and future stakeholder groups; (3) given the unintended negative consequences that have emerged out of humanity's hubris, how does this business seek to manage technology better to avoid making the mistakes of the past and learn from them; (4) how this business interfaces with governments, nongovernmental organization, and pressure groups does. ${ }^{10}$ These various suggestions are commensurate with the Principles for Responsible Management Education's declaration to integrate climate-related topics into management education. ${ }^{11}$

\section{Implications for Measurement and Monitoring}

The environmental, ethical tone from the top is set by senior leaders, and the organisation's environmental, ethical climate enables or constrains employees' moral actions. As alluded to above, the ideas presented here provide the basis for normative criteria for appraisal of the environmental ethics of individual leaders' moral character and ethical behavior as well as the ethical climate and culture of institutions and organisations. These criteria could be used to develop virtue-based assessments of environmental ethics, which could be used as the type of metrics that Carney (2021) and others have suggested, which could be used to hold companies and investors to account.

Previous research in business ethics and positive psychology offers proof-of-concept in that it is possible to: (1) develop and test measures for the general ethical culture in terms of "virtuousness" of organisations based on specific virtues derived from the business ethics literature (Kaptein, 2008); (2) measure 'moral competencies' (Morales-Sánchez \& Cabello-Medina, 2013) and associated issues of character including those of leaders (e.g., Sosik et al. 2012); (3) operationalise virtues of, for example " $[\mathrm{X}]$ would rather risk her/his job than do something that was unjust" (assessing the virtue of "fortitude"), "[X] respects the rights and integrity of others" (justice), and so on (Riggio et al., 2010). A similar approach could be applied to the environmental virtues outlined above; (4) demonstrate relationships between high levels of moral character (e.g., high levels of honesty-humility, empathic concern, and guilt-proneness) and regulation of behavior (e.g., positive short-term consequences versus negative long-term consequences giving concern for future consequences; Cohen et al., 2014). Our proposals and other research suggest that environmental virtues, including humility, are amenable to these kinds of approaches. The measurement and monitoring of senior leaders' and institutions' and organisations' environmental ethics in relation to the environment could be informative for stakeholders in exposing 


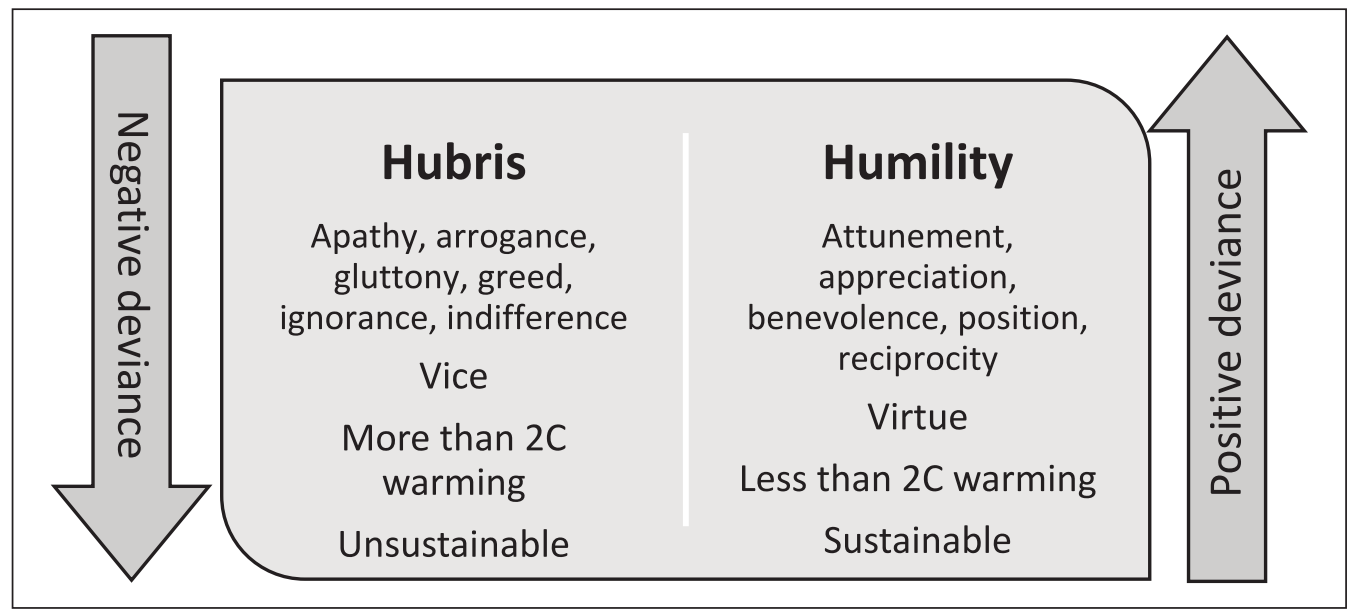

Figure I. A moral compass for environmental virtues and vices, deviances and sustainability.

organisations' negatively deviant or positively deviant attitudes towards the environment. A novel way of operationalising and presenting the results of such measurement could be in the form of an "environmental moral compass" (see Figure 1).

The idea of a compass is an appropriate metaphor because of its associations with determining "right direction," and discerning "right direction" from "wrong direction" (Grasso \& Tàbara, 2019). A geographical compass has four points (north, south, east, and west) and two dimensions, north-south and east-west. The environmental moral compass would be different because its purpose would be to discern positive deviance towards virtue (a metaphorical "true north") and away from negative deviance (vice). The environmental moral compass would have two cardinal points, humility (virtue), and hubris (vice) and a single bipolar dimension (humility-hubris). "North" and "South" are arbitrary and abstract concepts that are tied by metaphor to embodiment and spatial perception (north is "up," south is "down" ('up-north' and 'down-south' and UK English colloquiallisms) Meier et al., 2012). In the compass metaphor, north is the orientation towards environmental virtue, it represents positive deviance and encapsulates the cardinal environmental virtue of "humility." The opposite is the orientation towards environmental vice, it represents negative deviance and encapsulates the cardinal environmental vice of "hubris."

\section{Implications for Recursivity and Reflexivity}

The consideration of moral issues raises issues of recursivity and reflexivity; it affords actors the opportunity to surface and question their intuitive understandings about their place in nature and engage in reflective conversations about the situation they have helped create and the structures and systems within which these factors are embedded (Hulme, 2014). Climate change reflexivity (Davidson, 2012) involves reflecting on our values and taking responsibility for our actions' consequences, intended, or otherwise. The relationship between the Earth's climate and human beings is recursive to the extent that: (1) over the past 250 years, Homo sapiens has inadvertently, but nonetheless hubristically, modified the Earth's climate through GHG emissions in ways that have disturbed the integrity and stability of the whole-earth system and brought about negative unintended consequences; (2) the unintended negative consequences of the disturbance of the integrity and stability of the whole earth system has had a profound effect on Homo sapiens' perception of its relationship with the planet and its position in the natural order

It is argued in this article that a reflexive outcome of such a reappraisal is a humility which can reveal potentially profound and potentially disturbing insights. The whole-Earth system is 
"indifferent" in the matter of whether Homo sapiens has been hubristic, whether it is humble and contrite in light of its past actions, or whether Homo sapiens continues to exist or not. Humanity has anthropocentrically, and hubristically, assumed that it has primacy of place in the natural order and that the environment is impervious to, and inherently stable in the face of, its assaults. Arguably, "human exceptionalism" (Manuel-Navarrete \& Buzinde, 2010) is antecedent to hubris has a significant role to play in the climate crisis.

\section{Conclusion}

Viewed ecologically, the climate crisis can be seen as a potential "species-level adaptation failure" (Bateman \& Mann, 2016, p. 1052). The magnitude of the problem is such that it requires positively deviant moral leadership and stakeholder behaviours (including those of leaders, investors, consumers, and educators) that are committed to behaving in ways that demonstrate environmental humility, for example, in the virtues of attunement, appreciation, benevolence, position, and reciprocity. Negatively deviant leadership and stakeholder behaviours that adhere to arrogance, greed, apathy, and indifference only serve to compound the problem and enhance the possibility of irreversibility.

There are undoubtedly many problems, for example, stakeholders also need to guard against environmental virtues being used cynically as part of a "greenwashing strategy" or for personal aggrandisement or self-righteousness. Such behaviours represent nothing more than a façade for merely being seen to be adopting a humble posture primarily to improve their social legitimacy and moral authority without necessarily reexamining their internal practices or structural arrangements (Besio \& Pronzini, 2014). See also Reimagining Capitalism in a World on Fire by Harvard economist Rebecca Henderson (Henderson, 2020) and recent criticisms of the U.S. "Business Round Table" declaration on "stakeholder capitalism." Whilst many individuals are emotionally invested and morally concerned about the social and environmental consequences of climate change, they are also aware of their limited room to maneuver and are at the mercy of shareholder interests, wider structures and the political context (Wright \& Nyberg, 2017). While environmentally concerned individuals' actions are an invaluable contribution to progress, the positive deviance towards humility and away from hubris required to effect structural change resides with senior leaders in organisations, institutions, government, and wider society.

Whilst one's moral conscience holds individuals to account; the market can hold business leaders to account for their hubristic transgressions, and voters can hold politicians to account. The signs that the latter is happening in some countries is encouraging: in the United Kingdom's recent general election, anthropogenic climate change was at the forefront of discussions, and in Australia, the incumbent Prime Minister at the time of the heatwave and associated bush fires was held to account publicly by those who were suffering the immediate consequences. But organisational and political timescales are inherently short-term geared around shareholder dividends and general elections. The challenge for leadership is to structurally and culturally embed virtue and positive deviance regarding anthropogenic climate change within the corporate, public and political discourses.

This article has identified negative unintended consequences that a society's trust in its technology and its neglect of nature are having upon the stability of the whole-Earth system. The argument put forward is that hubris helped get us into this problem and humility can help get us out of it, and that regression to "business-as-usual," which may be comfortable for short-term shareholder and political interests, is a negatively deviant state and is no longer an option. Once the repercussions of the coronavirus epidemic have subsided, it will be "back to the future" of the climate crisis. Organisations and economies should be organised in ways that reflect humility towards nature. As the rational species per se, we are in the privileged position, unlike other species, of having the power of choice over our future. The challenge lies in the scale of the transgression and the concomitant scale of the structural response that is necessary to obviate the unintended negative consequences of humanity's hubris. 


\section{Declaration of Conflicting Interests}

The author(s) declared no potential conflicts of interest with respect to the research, authorship, and/or publication of this article.

\section{Funding}

The author(s) received no financial support for the research, authorship, and/or publication of this article.

\section{ORCID iD}

Vita Akstinaite (iD https://orcid.org/0000-0003-0313-7187

\section{Notes}

1. "https://climate.nasa.gov/causes/"; "https://www.metoffice.gov.uk/weather/climate-change/causes-ofclimate-change"; and "https://www.ncbi.nlm.nih.gov/pmc/articles/PMC5800116/" (accessed January 02, 2020).

2. "https://www.forbes.com/sites/solitairetownsend/2018/09/14/why-climate-storytelling-mustchange/\#2f2a2af97c72" (accessed December 19, 2019); "https://www.esquire.com/news-politics/ a30368633/global-climate-emissions-rise-2019-crisis/" "https://www.theguardian.com/commentisfree /2019/dec/29/the-climate-movement-is-about-to-get-more-political-and-thats-a-good-thing" (accessed January 02, 2020).

3. https://www.newscientist.com/article/2098365-ghastly-weather-what-frankenstein-can-tellus-on-climate-change/ (accessed January 02, 2020).

4. We are grateful to one of our anonymous reviewers for pointing out this important issue.

5. Mike Hulme is the U.K. climate scientist who was implicated in the 2009 "Climategate" affair when an email server at the University of East Anglia (UEA) was hacked an material used selectively by climate change deniers.

6. https://unesdoc.unesco.org/ark:/48223/pf0000188198 (accessed February 08, 2020).

7. The field of environmental ethics has grown since its inception to encompass many subfields (e.g., animal and human rights, deep ecology and eco-feminism, holistic environmental ethics, etc.) and different philosophical schools of thought (e.g., moral pragmatism and moral pluralism, as well as Aristotelian virtue theory; Light \& Rolston, 2003). The focus in this article is EVE.

8. We are grateful to one of our anonymous reviewers for this insightful suggestion.

9. https://insights.som.yale.edu/insights/what-is-ecological-economics

10. https://theconversation.com/science-cant-settle-what-should-be-done-about-climate-change-22727 (accessed January 07, 2020).

11. https://www.unprme.org/resource-docs/CopenhagenDeclarationFINAL.pdf (accessed January 07, 2020).

\section{References}

Ackerman, F., DeCanio, S. J., Howarth, R. B., \& Sheeran, K. (2009). Limitations of integrated assessment models of climate change. Climatic Change, 95(3-4), 297-315. https://doi.org/10.1007/s10584-0099570-x

Agrawal, A., \& Orlove, B. (2012). Cool heads for a hot world: Social sciences under a changing sky. Global Environmental Change, 22(2), 329-331. https://doi.org/10.1016/j.gloenvcha.2012.02.003

Akstinaite, V., Robinson, G., \& Sadler-Smith, E. (2020). Linguistic markers of CEO hubris. Journal of Business Ethics, 167(4), 687-705. https://doi.org/10.1007/s10551-019-04183-y

Aragon-Correa, J. A., Marcus, A., Rivera, J., \& Kenworthy, A. (2017). Sustainability management teaching resources and the challenge of balancing planet, people, and profits. Academy of Management Learning \& Education, 16(3), 469-483. https://doi.org/10.5465/amle.2017.0180

Arjoon, S. (2005). Corporate governance: An ethical perspective. Journal of Business Ethics, 61(4), 343352. https://doi.org/10.1007/s10551-005-7888-5

Arnold, D. G., \& Bustos, K. (2005). Business, ethics, and global climate change. Business and Professional Ethics Journal, 24(1/2), 103-130. https://doi.org/10.5840/bpej2005241/26 
Audi, R. (2012). Virtue ethics as a resource in business. Business Ethics Quarterly, 22(2), 273-291. https:// doi.org/10.5840/beq201222220

Bailey, A. (2018). Culture in financial services: A regulator's perspective. Bank of England. https://www. bankofengland.co.uk/speech/2016/culture-in-financial-services-a-regulators-perspective

Bateman, T. S., \& Mann, M. E. (2016). The supply of climate leaders must grow. Nature Climate Change, 6(12), 1052-1054. https://doi.org/10.1038/nclimate3166

Beck, U. (1997). The reinvention of politics: Rethinking modernity in the global social order. Polity Press.

Beinart, P. (2010). The Icarus Syndrome: A history of American hubris. Harper Perennial.

Besio, C., \& Pronzini, A. (2014). Morality, ethics, and values outside and inside organisations: An example of the discourse on climate change. Journal of Business Ethics, 119(3), 287-300. https://doi. org/10.1007/s10551-013-1641-2

Bina, O., \& Vaz, S. G. (2011). Humans, environment and economies: From vicious relationships to virtuous responsibility. Ecological Economics, 72(December), 170-178. https://doi.org/10.1016/j. ecolecon.2011.09.029

Bordoni, C. (2019). Hubris and progress: A future born of presumption. Oxford University Press. https:// doi.org/10.4324/9780429431265

Brugger, J., \& Crimmins, M. (2013). The art of adaptation: Living with climate change in the rural American Southwest. Global Environmental Change, 23(6), 1830-1840. https://doi.org/10.1016/j. gloenvcha.2013.07.012

Burns, T. R., \& Machado, N. (2010). Technology, complexity, and risk. Part II: A social systems perspective on the discourses and regulation of the hazards of sociotechnical systems. Sociologia, 62, 97-131. https://revistas.rcaap.pt/sociologiapp/article/view/7803

Cafaro, P. (2005). Thoreau, Leopold, and Carson: Toward environmental virtue ethics. In R. Sandler \& P. Cafaro (Eds.), Environmental virtue ethics (pp. 31-44). Rowman \& Littlefield.

Cafaro, P., \& Sandler, R. D. (2010). Virtue ethics and the environment. Springer. https://doi.org/10.1007/97894-007-0420-6

Cairns, D. (2020). Aristotle on hybris and injustice. In Les philosophes face au vice, de Socrate à Augustin (pp. 147-174). Brill. https://doi.org/10.1163/9789004432390_010

Carney, M. (2021). Values: Building a better world for all. William Collins.

Castree, N., Adams, W. M., Barry, J., Brockington, D., Büscher, B., Corbera, E., Demeritt, D., Duffy, R., Felt, U., Neves, K., Newell, P., Pellizzoni, L., Rigby, K., Robbins, P., Robin, L., Rose, D. B., Ross, A., Schlosberg, A., Sörlin, S., . . Wynne, B. (2014). Changing the intellectual climate. Nature Climate Change, 4(9), 763-768. https://doi.org/10.1038/nclimate2339

Chang, G., \& Diddams, M. (2009). Hubris or humility: Cautions surrounding the construct and selfdefinition of authentic leadership. Academy of Management Proceedings, 2009(1), 1-6. https://doi. org/10.5465/ambpp.2009.44247841

Cinner, J. E., \& Barnes, M. L. (2019). Social dimensions of resilience in social-ecological systems. One Earth, 1(1), 51-56. https://doi.org/10.1016/j.oneear.2019.08.003

Cohen, T. R., Panter, A. T., Turan, N., Morse, L., \& Kim, Y. (2014). Moral character in the workplace. Journal of Personality and Social Psychology, 107(5), 943-963.

Costanza, R., Cumberland, J. H., Daly, H., Goodland, R., Norgaard, R. B., Kubiszewski, I., \& Franco, C. (2014). An introduction to ecological economics. CRC Press. https://doi.org/10.1201/b17829

Crossan, M., Mazutis, D., \& Seijts, G. (2013). In search of virtue: The role of virtues, values and character strengths in ethical decision making. Journal of Business Ethics, 113(4), 567-581. https://doi. org/10.1007/s10551-013-1680-8

Davidson, D. (2012). Analysing responses to climate change through the lens of reflexivity. British Journal of Sociology, 63(4), 616-640. https://doi.org/10.1111/j.1468-4446.2012.01429.x

De Haan, E., \& Kasozi, A. (2014). The leadership shadow: How to recognise and avoid derailment, hubris and overdrive. Kogan Page.

Eason, K. D. (1982). The process of introducing information technology. Behaviour \& Information Technology, 1(2), 197-213. https://doi.org/10.1080/01449298208914447

Ehrlich, P. R., \& Ehrlich, A. H. (2004). One with Nineveh: politics, consumption, and the human future. Island Press.

Folkersen, M. V., Fleming, C. M., \& Hasan, S. (2019). Depths of uncertainty for deep-sea policy and legislation. Global Environmental Change, 54(January), 1-5. https://doi.org/10.1016/j.gloenvcha.2018.11.002 
Ford, R. (2006). Why we fail: How hubris, hamartia, and anagnosis shape organisational behavior. Human Resource Development Quarterly, 17(4), 481-489. https://doi.org/10.1002/hrdq.1187

Frasz, G. (2005). Benevolence as an environmental virtue. In R. Sandler \& P. Cafaro (Eds.), Environmental virtue ethics (pp.121-139). Rowman \& Littlefield.

Gardiner, S. M. (2004). Ethics and global climate change. Ethics, 114(3), 555-600. https://doi. org $/ 10.1086 / 382247$

Gardiner, S. M. (2006). A perfect moral storm: Climate change, intergenerational ethics and the problem of moral corruption. Environmental Values, 15(3),397-413. https://doi.org/10.3197/096327106778226293

Gibson, K., \& O'Donovan, G. (2007). Corporate governance and environmental reporting: An Australian study. Corporate Governance: An International Review, 15(5), 944-956. https://oi.org/10.1111/ j.1467-8683.2007.00615.x

Graafland, J., \& Van de Ven, B. (2006). Strategic and moral motivation for corporate social responsibility. Journal of Corporate Citizenship, 22, 111-123. https://doi.org/10.9774/GLEAF.4700.2006.su.00012

Grasso, M., \& Tàbara, J. D. (2019). Towards a moral compass to guide sustainability transformations in a high-end climate change world. Sustainability, 11(10), 2971. https://doi.org/10.3390/su11102971

Grenberg, J. (2005). Kant and the ethics of humility: A story of dependence, corruption and virtue. Cambridge University Press. https://doi.org/10.1017/CBO9780511627859

Harari, Y. N. (2014). Sapiens: A brief history of humankind. Random House.

Harrison, M. I., Koppel, R., \& Bar-Lev, S. (2007). Unintended consequences of information technologies in health care: An interactive sociotechnical analysis. Journal of the American Medical Informatics Association, 14(5), 542-549. https://doi.org/10.1197/jamia.M2384

Haynes, K. T., Hitt, M. A., \& Campbell, J. T. (2015). The dark side of leadership: Towards a mid-range theory of hubris and greed in entrepreneurial contexts. Journal of Management Studies, 52(4), 479-505. https://doi.org/10.1111/joms.12127

Heffernan, M. (2012). Willful blindness. Simon \& Schuster.

Helbing, D. (2009). Managing complexity in socio-economic systems. European Review, 17(2), 423-438. https://doi.org/10.1017/S1062798709000775

Henderson, R. (2020). Reimagining capitalism in a world on fire. Hachette.

Higgs, E. (2012). History, novelty and virtue in ecological restoration. In A Thompson \& J. Bendik-Keymer (Eds.), Ethical adaptation to climate change: Human virtues of the future (pp. 81-102). MIT Press. https://doi.org/10.7551/mitpress/9780262017534.003.0005

Hoffman, A. J. (2005). Climate change strategy: The business logic behind voluntary greenhouse gas reductions. California Management Review, 47(3), 21-46. https://doi.org/10.2307/41166305

Hoffman, A. J., \& Haigh, N. (2011). Positive deviance for a sustainable world: Linking sustainability and positive organisational scholarship. In K. S. Cameron \& G. M. Spreitzer (Eds.), The Oxford handbook of positive organizational scholarship. https://webuser.bus.umich.edu/ajhoff/pub_academic/2011\%20 Pos\%20Deviance\%20for\%20Sust\%20World.pdf

Hormio, S. (2017). Can corporations have (moral) responsibility regarding climate change mitigation? Ethics, Policy \& Environment, 20(3), 314-332. https://doi.org/10.1080/21550085.2017.1374015

Hulme, M. (2014). Climate change and virtue: An apologetic. Humanities, 3(3), 299-312. https://doi. org/10.3390/h3030299

International Panel on Climate Change. (2014). Climate Change 2014: Mitigation of climate change: Working Groups I, II and III to the Fifth Assessment report of the intergovernmental panel on climate change. Author. https://doi.org/10.1017/CBO9781107415416

Jackson, T. (2009). Prosperity without growth? The transition to a sustainable economy. Sustainable Development Commission. http://www.sd-commission.org.uk/data/files/publications/prosperity_without growth_report.pdf

Jamieson, D. (2007). The moral and political challenges of climate change. In S. C. Moser (Ed.), Creating a climate for change: Communicating climate change and facilitating social change (pp. 475-482). Cambridge University Press. https://doi.org/10.1017/CBO9780511535871.033

Jamieson, D. (2010). When utilitarians should be virtue theorists. In S. M. Gardiner, S. Caney, D Jamieson, \& H. Shue (Eds.), Climate ethics: Essential readings (pp. 315-331). Oxford University Press. https:// doi.org/10.1093/oso/9780195399622.003.0028

Jasanoff, S. (2007). Technologies of humility. Nature, 450, 33. https://doi.org/10.1038/450033a 
Jasanoff, S. (2021). Humility in the Anthropocene. Globalizations. Advance online publication. https://doi. org/10.1080/14747731.2020.1859743

Jones, D. S. (2020). COVID-19, history, and humility. Centaurus, 62(2), 370-380. https://onlinelibrary. wiley.com/doi/full/10.1111/1600-0498.12296

Kaptein, M. (2008). Developing and testing a measure for the ethical culture of organisations: The corporate ethical virtues model. Journal of Organizational Behavior, 29(7), 923-947. https://doi.org/10.1002/job.520

Kaya, Y. (1989). Impact of carbon dioxide emission control on GNP growth: Interpretation of proposed scenarios. Intergovernmental Panel on Climate Change/Response Strategies Working Group.

Kennedy, D. (2012). Rooftop revolution: How solar power can save our economy-and our planet-from dirty energy. Berrett-Koehler.

Ladd, A. E. (2012). Pandora's well: Hubris deregulation fossil fuels and the BP oil disaster in the Gulf. American Behavioral Scientist, 56(1), 104-127. https://doi.org/10.1177/0002764211409195

Lane, M. (2011). Eco-republic: Ancient thinking for a green age. Peter Lang. https://doi.org/10.2307/j. ctt1r2df3

Langer, E. J. (1975). The illusion of control. Journal of Personality and Social Psychology, 32(2), 311-328. https://doi.org/10.1037/0022-3514.32.2.311

Leavitt, H. J. (1965). Applied organisational change in industry: Structural, technological and humanistic approaches. In J. G. March (Ed.), Handbook of organisations (pp. 1144-1170). Rand McNally.

Leopold, A. (2003). The land ethic. In A. Light \& H. Rolston III (Eds.), Environmental ethics: An Anthology (pp. 38-46). Blackwell. (Original work published 1949)

Li, J., Swinbank, R., Ding, R., \& Duan, W. (2013). Dynamics and predictability of high-impact weather and climate events. Bulletin of the American Meteorological Society, 94(12), ES179-ES182. https:// doi.org/10.1175/BAMS-D-12-00213.1

Lin, H., Zeng, S., Wang, L., Zou, H., \& Ma, H. (2016). How does environmental irresponsibility impair corporate reputation? A multi-method investigation. Corporate Social Responsibility and Environmental Management, 23(6), 413-423. https://doi.org/10.1002/csr.1387

Lindsey, R., \& Santos, G. (2020). Addressing transportation and environmental externalities with economics: Are policy makers listening? Research in Transportation Economics, 82(October), 100872. https:// doi.org/10.1016/j.retrec.2020.100872

Loebach, P., \& Korinek, K. (2019). Disaster vulnerability, displacement, and infectious disease: Nicaragua and Hurricane Mitch. Population and Environment, 40(4), 434-455. https://doi.org/10.1007/s11111019-00319-4

Lowenstein, R. (2000). When genius failed: The rise and fall of long-term capital management. Random House.

MacIntyre, A. (1984). After virtue. Duckworth.

MacKay, R. B., \& Chia, R. (2013). Choice, chance, and unintended consequences in strategic change: A process understanding of the rise and fall of NorthCo Automotive. Academy of Management Journal, 56(1), 208-230. https://doi.org/10.5465/amj.2010.0734

Manuel-Navarrete, D., \& Buzinde, C. N. (2010). Socio-ecological agency: From "human exceptionalism" to coping with "exceptional" global environmental change. In M. R. Redclift \& G. Woodgate International handbook of environmental sociology (pp. 136-149). https://doi.org/10.4337/9781849805520.00018

Manuel-Navarrete, D., Morehart, C., Tellman, B., Eakin, H., Siqueiros-García, J. M., \& Aguilar, B. H. (2019). Intentional disruption of path-dependencies in the Anthropocene: Gray versus green water infrastructure regimes in Mexico City, Mexico. Anthropocene, 26(June), 100209. https://doi.org/10.1016/j. ancene.2019.100209

Mason, R. O. (2004). Lessons in organisational ethics from the Columbia disaster: Can a culture be lethal? Organizational Dynamics, 33(2), 128-142. https://doi.org/10.1016/j.orgdyn.2004.01.002

Max-Neef, M. (2010). The world on a collision course and the need for a new economy: Contribution to the 2009 royal colloquium. Ambio, 39(3), 200-210. https://doi.org/10.1007/s13280-010-0028-1

McIntosh, A. (2012). Hell and high water: Climate change, hope and the human condition. Birlinn.

McManus, J. (2018). Hubris and unethical decision making: The tragedy of the uncommon. Journal of Business Ethics, 149(1), 169-185. https://doi.org/10.1007/s10551-016-3087-9

Meier, B. P., Schnall, S., Schwarz, N., \& Bargh, J. A. (2012). Embodiment in social psychology. Topics in Cognitive Science, 4(4), 705-716. https://doi.org/10.1111/j.1756-8765.2012.01212.x 
Midgley, M. (2003). The myths we live by. Routledge. https://doi.org/10.4324/9780203480922

Morales-Sánchez, R., \& Cabello-Medina, C. (2013). The role of four universal moral competencies in ethical decision-making. Journal of Business Ethics, 116(4), 717-734. https://doi.org/10.1007/s10551013-1817-9

Morris, G. P., Reis, S., Beck, S. A., Fleming, L. E., Adger, W. N., Benton, T. G., \& Depledge, M. H. (2017). Scoping the proximal and distal dimensions of climate change on health and wellbeing. Environmental Health, 16(1), 69-76. https://doi.org/10.1186/s12940-017-0329-y

Morris, J. A., Brotheridge, C. M., \& Urbanski, J. C. (2005). Bringing humility to leadership: Antecedents and consequences of leader humility. Human Relations, 58(10), 1323-1350. https://doi. org/10.1177/0018726705059929

Mumford, E. (2006). The story of sociotechnical design: Reflections on its successes, failures and potential. Information Systems Journal, 16(4), 317-342. https://doi.org/10.1111/j.1365-2575.2006.00221.x

Nelson, D. R., Bledsoe, B. P., \& Shepherd, J. M. (2020). From hubris to humility: Transcending original sin in managing hydroclimatic risk. Anthropocene, 30(June), 100239. https://doi.org/10.1016/j. ancene.2020.100239

Nelson, J. A. (2013). Ethics and the economist: What climate change demands of us. Ecological Economics, 85(January), 145-154. https://doi.org/10.1016/j.ecolecon.2011.07.029

Ng, E. S., Schweitzer, L., \& Lyons, S. T. (2010). New generation, great expectations: A field study of the millennial generation. Journal of Business and Psychology, 25(2), 281-292. https://doi.org/10.1007/ s10869-010-9159-4

Niemann, M. (2017). Hubris and humility in environmental thought. In U. K. Heise, J. Christensen, \& M. Niemann (Eds.), The Routledge companion to the environmental humanities (pp. 263-273). Routledge. https://doi.org/10.4324/9781315766355-37

Nussbaum, M. C. (1988). Non-relative virtues: An Aristotelian approach. Midwest Studies in Philosophy, 13, 32-53. https://www.wider.unu.edu/sites/default/files/WP32.pdf

Nyberg, D., \& Wright, C. (2012). Justifying business responses to climate change: Discursive strategies of similarity and difference. Environment and Planning A: Economy and Space, 44(8), 1819-1835. https://doi.org/10.1068/a44565

O'Neill, J., Holland, A., \& Light, A. (2008). Environmental values. Routledge. https://doi. org/10.4324/9780203495452

Oreskes, N. (2004). The scientific consensus on climate change. Science, 306(5702), 1686. https://doi. org/10.1126/science.1103618

Otto, F. E., Philip, S., Kew, S., Li, S., King, A., \& Cullen, H. (2018). Attributing high-impact extreme events across timescales: A case study of four different types of events. Climatic Change, 149(3-4), 399-412. https://doi.org/10.1007/s10584-018-2258-3

Owen, D., \& Davidson, J. (2009). Hubris Syndrome: An acquired personality disorder? A study of US presidents and UK prime ministers over the last 100 years. Brain, 132(5), 1396-1406. https://doi. org/10.1093/brain/awp008

Owen, R., Macnaghten, P., \& Stilgoe, J. (2012). Responsible research and innovation: From science in society to science for society, with society. Science and Public Policy, 39(6), 751-760. https://doi. org $/ 10.1093 / \mathrm{scipol} / \mathrm{scs} 093$

Owens, B. P., Johnson, M. D., \& Mitchell, T. R. (2013). Expressed humility in organisations: Implications for performance, teams, and leadership. Organization Science, 24(5), 1517-1538. https://doi.org/10.1287/ orsc. 1120.0795

Palmer, C. (2003). An overview of environmental ethics. In A. Light \& H. Rolston III (Eds.), Environmental ethics: An anthology (pp. 15-37). Blackwell.

Pasmore, W. A. (1988). Designing effective organisations: The sociotechnical systems perspective. Wiley.

Perrow, C. (1984). Normal accidents: Living with high-risk systems. Basic Books.

Petit, V., \& Bollaert, H. (2012). Flying too close to the sun? Hubris among CEOs and how to prevent it. Journal of Business Ethics, 108(3), 265-283. https://doi.org/10.1007/s10551-011-1097-1

Picone, P. M., Dagnino, G. B., \& Minà, A. (2014). The origin of failure: A multidisciplinary appraisal of the hubris hypothesis and proposed research agenda. Academy of Management Perspectives, 28(4), 447-468. https://doi.org/10.5465/amp.2012.0177 
Pidgeon, N. F., Lorenzoni, I., \& Poortinga, W. (2008). Climate change or nuclear power-No thanks! A quantitative study of public perceptions and risk framing in Britain. Global Environmental Change, 18(1), 69-85. https://doi.org/10.1016/j.gloenvcha.2007.09.005

Piff, P. K., Dietze, P., Feinberg, M., Stancato, D. M., \& Keltner, D. (2015). Awe, the small self and prosocial behaviour. Journal of Personality and Social Psychology, 108(6), 883-899.

Rammel, C., Stagl, S., \& Wilfing, H. (2007). Managing complex adaptive systems: A co-evolutionary perspective on natural resource management. Ecological Economics, 63(1), 9-21. https://doi.org/10.1016/j. ecolecon.2006.12.014

Rand, T. (2010). Kick the fossil fuel habit: 10 Clean technologies to save our world. Ecoten.

Rescher, N. (1996). Process metaphysics: An introduction to process philosophy. SUNY Press. https://doi. org/10.5840/process 1996252

Rich, N. (2019). Losing earth: The decade we could have stopped climate change. Farrar, Straus and Giroux.

Riggio, R. E., Zhu, W., Reina, C., \& Maroosis, J. A. (2010). Virtue-based measurement of ethical leadership: The Leadership Virtues Questionnaire. Consulting Psychology Journal: Practice and Research, 62(4), 235-250. https://doi.org/10.1037/a0022286

Roberts, K. H., \& Bea, R. G. (2001). When systems fail. Organizational Dynamics, 29(3), 179-191. https:// doi.org/10.1016/S0090-2616(01)00025-0

Rolston, H. (1988). Environmental ethics. Temple University Press.

Rolston, H. (2003). The value of nature and the nature of value. In A. Light \& H. Rolston III (Eds.), Environmental ethics: An anthology (pp. 131-142). Blackwell.

Rousseau, S., \& Deschacht, N. (2020). Public awareness of nature and the environment during the COVID19 crisis. Environmental and Resource Economics, 76(4), 1149-1159. https://doi.org/10.1007/s10640020-00445-w

Sadler-Smith, E. (2012). Before virtue: Biology, brain, behavior, and the "moral sense." Business Ethics Quarterly, 22(2), 351-376. https://doi.org/10.5840/beq201222223

Sadler-Smith, E. (2013). Toward organisational environmental virtuousness. Journal of Applied Behavioral Science, 49(1), 123-148. https://doi.org/10.1177/0021886312471856

Sadler-Smith, E. (2019). Hubristic leadership. Sage. https://doi.org/10.4135/9781529714838

Sadler-Smith, E., Akstinaite, V., Robinson, G., \& Wray, T. (2017). Hubristic leadership: A review. Leadership, 13(5), 525-548. https://doi.org/10.1177/1742715016680666

Sadler-Smith, E., \& Cojuharenco, I. (2020). Business schools and hubris: Cause or cure? Academy of Management Learning \& Education, 20(2). https://doi.org/10.5465/amle.2019.0289

Sadler-Smith, E., \& Tourish, D. (2021). Hubris in management. In Oxford research encyclopedia in business and management. Oxford University Press.

Sandler, R. L. (2005). Introduction: Environmental virtue ethics. In R. Sandler \& P. Cafaro (Eds.), Environmental virtue ethics (pp. 1-12). Rowman \& Littlefield.

Sandler, R. L. (2012). Global warming and virtues of ecological restoration. In A Thompson \& J BendikKeymer (Eds.), Ethical adaptation to climate change: Human virtues of the future (pp.63-80). MIT Press. https://doi.org/10.7551/mitpress/9780262017534.003.0004

Sandler, R. L. (2013). Environmental virtue ethics. In H. LaFollette (Ed.), The international encyclopaedia of ethics (pp. 1665-1674). John Wiley. https://doi.org/10.1002/9781444367072.wbiee090

Sanne, C. (2002). Willing consumers - or locked-in? Policies for a sustainable consumption. Ecological Economics, 42(1-2), 273-287. https://doi.org/10.1016/S0921-8009(02)00086-1

Schultz, W., \& Zelezny, L. (1999). Values as predictors of environmental attitudes: Evidence for consistency across 14 countries. Journal of Environmental Psychology, 19(3), 255-265. https://doi. org/10.1006/jevp.1999.0129

Solomon, R. C. (2003). Victims of circumstances? A defense of virtue ethics in business. Business Ethics Quarterly, 13(1), 43-62. https://doi.org/10.5840/beq20031314

Sosik, J. J., Gentry, W. A., \& Chun, J. U. (2012). The value of virtue in the upper echelons: A multisource examination of executive character strengths and performance. Leadership Quarterly, 23(3), 367-382. https://doi.org/10.1016/j.leaqua.2011.08.010

Sousa, M., \& van Dierendonck, D. (2017). Servant leadership and the effect of the interaction between humility, action, and hierarchical power on follower engagement. Journal of Business Ethics, 141(1), 13-25. https://doi.org/10.1007/s10551-015-2725-y 
Stephens, C. (2012). Biodiversity and global health: Hubris, humility and the unknown. Environmental Research Letters, 7(1), 011008. https://doi.org/10.1088/1748-9326/7/1/011008

Stern, N. (2006). What is the economics of climate change. World Economics, 7(2), 1-10. https://www. humphreyfellowship.org/system/files/stern_summary__what_is_the_economics_of_climate_change. pdf

Sullivan, G. B., \& Hollway, J. (2014). Collective pride and collective hubris in organisations: Understanding collective pride and group identity. In G. B. Sullivan (Ed.), New directions in emotion theory, research and practice (pp. 80-92). Routledge. https://doi.org/10.4324/9781315767680-7

Taleb, N. N., Goldstein, D. G., \& Spitznagel, M. W. (2009, October). The six mistakes executives make in risk management. Harvard Business Review. https://hbr.org/2009/10/the-six-mistakes-executivesmake-in-risk-management

Trivers, R. (2011). The folly of fools: The logic of deceit and self-deception in human life. Basic Books.

Trumbull, D. (2010). Hubris: A primal danger. Psychiatry, 73(4), 341-351. https://doi.org/10.1521/ psyc.2010.73.4.341

UNESCO. (2010). The ethical implications of global climate change [Report by the World Commission on the Ethics of Scientific Knowledge and Technology (COMEST)]. http://www.gci.org.uk/Documents/ UNESCO_COMEST_pdf

United Nations Environment Programme. (2015). Sustainable production and consumption: A Handbook for policy makers. Author. https://wedocs.unep.org/handle/20.500.11822/9660

van Wensveen, L. (2005). Cardinal environmental virtues: A neurobiological perspective. In R. Sandler \& P. Cafaro (Eds.), Environmental virtue ethics (pp. 173-194). Rowman \& Littlefield.

Verbruggen, A. (2013). Revocability and reversibility in societal decision-making. Ecological Economics, 85(January), 20-27. https://doi.org/10.1016/j.ecolecon.2012.10.011

Wardekker, J. A., Petersen, A. C., \& van Der Sluijs, J. P. (2009). Ethics and public perception of climate change: Exploring the Christian voices in the US public debate. Global Environmental Change, 19(4), 512-521. https://doi.org/10.1016/j.gloenvcha.2009.07.008

Weber, J., \& Urick, M. J. (2017). Examining the millennials' ethical profile: Assessing demographic variations in their personal value orientations. Business and Society Review, 122(4), 469-506. https://doi. org/10.1111/basr.12128

Wenz, P. (2005). Synergistic environmental virtues: Consumerism and human flourishing. In R. Sandler \& P. Cafaro (Eds.), Environmental virtue ethics (pp. 197-194). Rowman \& Littlefield.

Whetstone, J. T. (2001). How virtue fits within business ethics. Journal of Business Ethics, 33(2), 101-114. https://doi.org/10.1023/A:1017554318867

Whetstone, J. T. (2005). A framework for organisational virtue: The inter-relationship of mission, culture and leadership. Business Ethics: The Environment \& Responsibility, 14(4), 367-378. https://doi. org/10.1111/j.1467-8608.2005.00418.x

Wilson, E. O. (1994). The diversity of life. Penguin.

Wright, C., \& Nyberg, D. (2015). Climate change, capitalism, and corporations. Cambridge University Press. https://doi.org/10.1017/CBO9781139939676

Wright, C., \& Nyberg, D. (2017). An inconvenient truth: How organisations translate climate change into business as usual. Academy of Management Journal, 60(5), 1633-1661. https://doi.org/10.5465/ amj.2015.0718

\section{Author Biographies}

Eugene Sadler-Smith is a professor of organizational behaviour at University of Surrey. His current research interests are intuition and hubris. He is the author of a number of books and his research has been featured on BBC Radio 4, The Insight Channel, and in The Times. His previous editorial responsibilities have included 6-year term of office as joint editor-in-chief of management learning.

Vita Akstinaite is a lecturer in leadership at ISM University of Management and Economics. Her research interests are in hubris, linguistic markers, and nontraditional research methods, including at-a-distance analysis, computational linguistics, and machine learning. She is a winner of the Australian Institute of Management Aspire Award 2019 and a cofounder of The Hubris Hub. In addition, she is a business consultant with many years' experience in working on business intelligence programmes in information technology industry. 